\title{
Pengaruh Inkuiri Terbimbing Berbasis Science, Technology, Engineering, Math (STEM) terhadap Penguasaan Konsep Siswa SMA pada Materi Fluida Statis
}

\author{
Khusnul Khotimah ${ }^{1}$, Edi Supriana ${ }^{1}$, Parno $^{1}$ \\ ${ }^{1}$ Pendidikan Fisika-Universitas Negeri Malang
}

\begin{tabular}{l}
\hline \hline INFO ARTIKEL \\
\hline Riwayat Artikel: \\
Diterima: 07-01-2020 \\
Disetujui: $14-07-2020$ \\
\hline
\end{tabular}

\section{Kata kunci:}

mastery of concepts; guided inquiry; static fluid; penguasaan konsep; inkuiri terbimbing; fluida statis

\begin{abstract}
ABSTRAK
Abstract: The ability to master concepts can be developed with the Guided Inquiry learning model. The purpose of this study is to find out how the STEM-based Guided Inquiry learning model influences the mastery of the concept of high school students on static fluid material. This research was conducted at SMAN 6 Malang class XI, the subject of this study were 34 students. This research is a mixed method embedded experimental model. With the test of mastery of concepts in the form of essays as many as 5 items. From the results of the research conducted showed that there are differences in the mastery of the concept of students before and after getting STEM-based guided inquiry learning on static fluid material.
\end{abstract}

\begin{abstract}
Abstrak: Kemampuan penguasaan konsep dapat dikembangkan dengan model pembelajaran Inkuiri Terbimbing. Tujuan dari penelitian ini ialah untuk mengetahui bagaimana pengaruh model pembelajran Inkuiri Terbimbing berbasis STEM terhadapa penguasaan konsep siswa SMA pada materi fluida statis. Penelitian ini dilakukan di SMAN 6 Malang kelas XI subjek penelitian ini berjumlah 34 siswa. Penelitian ini berjenis mixed method embedded experimental model. Dengan soal tes penguasaan konsep yang berupa esai sebanyak lima butir soal. Dari hasil penelitian yang dilakukan menunjukkan bahwa ada perbedaan penguasaan konsep siswa sebelum dan sesudah mendapatkan pembelajaran inkuiri terbimbing berbasis STEM pada materi fluida statis.
\end{abstract}

\author{
Alamat Korespondensi: \\ Khusnul Khotimah \\ Pendidikan Fisika \\ Universitas Negeri Malang \\ Jalan Semarang 5 Malang \\ E-mail: khuskhotimah19@gmail.com
}

Penguasaan konsep merupakan pengetahuan fisika siswa terhadap sub materi-materi yang akan diajarkan, kemudian dapat menggunakannya dan memahami. Joyce, Weil, and Calhoun (2009) menngemukakan bahwa fokus dari belajar konsep adalah pada pengodean bagaimana subjek secara bertahap menggunakan dan memperoleh informasi tentang suatu konsep melalui pengategorisasian (categorizing), yaitu mengidentifikasi dan menempatkan objek-objek atau kejadian-kejadian ke dalam kelaskelas berdasarkan kriteria tertentu. Penguasaan konsep pada penelitian ini menggunakan Taksonomi Bloom yang sudah direvisi oleh (Anderson and Krathwohl, 2010). Beberapa penelitian menunjukkan banyaknya siswa yang kurang dalam penguasaan konsep ini, seperti penelitian yang dilakukan (Marlis, 2015); (Simanjuntak, 2014) dalam penelitian ini menunjukkan bahwa penguasaan konsep siswa rendah pada materi fluida statis. Hal ini juga diperkuat oleh penelitian (Goszwski, et al. 2013) yang juga menyatakan bahwa siswa masih banyak yang belum mengerti tentang cara mengidentifikasi sebuah fenomena. Dalam sebuah penelitian lain menyatakan bahwa siswa yang hanya diberikan pembelajaran melalui ceramah tanpa ada pengetahuan matematis akan mengalami kesulitan saat menjawab soal sehingga mereka menjawab hanya dengan matematis tanpa ada pembahasan konsep yang jelas (Hung and Jonassen 2006); (Jonassen 2003); (Van Heuvelen 1991); (Maloney et al, 2001).

Materi fluida statis merupakan salah satu materi yang kaya konsep. Materi fluida statis terkait erat dengan fenomenafenomena alam, seperti terapung, tenggelam, dan melayang. Penguasaan konsep siswa terhadap konsep terapung dan tenggelam membutuhkan kemampuan analisis gaya apung dan gravitasi (Yin, Tomita, and Shavelson, 2008). Sementara dalam topik tekanan hidrostatis, siswa dituntut untuk memahami konsep tekanan oleh fluida, massa jenis, dan tekanan pada titik-titik yang segaris horizontal pada fluida sejenis (Loverude, Heron, and Kautz 2010). Pada materi fluida statis sering siswa mengalami kesalahpahaman tentang konsep yang mereka gunakan. Konsep fisika membutuhkan pemahaman yang koheren terhadap aspek pengetahuan kualitatif dan kuantitatif. Menurut Yusro dan Sasono (2016) Wospakrik (1993) kurangnya pemahaman konsep siswa mengakibatkan banyaknya kesalahpahaman yang timbul. Pembelajaran yang dilakukan bertujuan agar dapat mengetahui kesalahpahaman siswa terhadap konsep yang mereka pelajari. 
Selain itu, penelitian lain memnunjukkan banyakknya siswa yang salah dalam menerapkan konsep yang mereka pelajari. Salah satu penelitian menunjukkan bahwa penerapan model inkuiri terbimbing dapat meninngkatkan kemampuan siswa dalam pembelajaran (Andriani, 2011); (Yusro dan Sasono 2016); (Hadiati dan Pramuda, 2013). Penerapan model inkuiri terbimbing sangat efektif untuk meningkatkan penguasaan konsep siswa (Praptiwi, Sarwi, dan Handayani 2012) (Shih, Chuang, and Hwang 2010). Salah satu peneliti juga mengungkapkan bahwa pembelajaran yang menghasilkan sebuah produk akan lebih bermanfaat daripada pembelajaran yang hanya materi (Capraro, 2013).

Dalam sebuah program integrasi STEM di sebuah pembelajaran yaitu sebuah program yang membelajarkan dan menggabungkan dua atau pun lebih bidang ilmu-ilmu yang terdapat dalam STEM (Laboy-Rush, 2011). Bukan hanya sebuah program dalam penelitian lain juga menyebutkan bahwa STEM Education perlu diintegrasikan dalam pendidikan sehingga mendapatkan desain untuk meningkatkan sebuah pemahaman siswa terhadap aktivitas profesional STEM dalam kehidupan nyata dan menghilangkan batasan-batasan dari disiplin sebuah ilmu (Asghar, Ellington, and Rice, 2012); (Roberts, 2012). Penelitian lain juga mengungkapkan bahwa pembelajaran STEM dapat meningkatkan sebuah kepekaan terhadap siswa terhadap isu dan masalah-masalah global yang sebenarnya (Kementrian Pendidikan Malysia 2016). STEM juga dapat meningkatkan kemampuan siswa (Afriana, Permanasari, dan Fitriani, 2016). Menurut (Kim and Cho 2015); (Bilgin, Karakuyu, and Ay 2015); (Morrison 2006) dalam (Stohlmann, Moore, and Roehrig, 2012) STEM membelajarkan dengan kehidupan. Dari beberapa penelitian sudah banyak membuktikan bahwa STEM merupakan penerapan pengetahuan yang dapat menyelesaikan masalah.

\section{METODE}

Jenis penelitian yang akan digunakan ialah mixed method desain embedded Experimental Model. Subjek dari penelitian ini ialah siswa SMAN 6 Malang kelas XI IPA semester II tahun pelajaran 2018/2019. Sebelum adanya perlakuan para siswa diberikan beberapa soal pretest dan sesudah dilakukan perlakuan pembelajaran siswa juga diberi soal yang sama dengan soal pretest atau yang disebut dengan posttest. Data kuantitatif berupa hasil skor nilai pretest dan posttest. Penelitian ini menggunakan penguasaan konsep taksonomi bloom $\mathrm{C} 2-\mathrm{C} 4$ yang akan dijelaskan pada tabel 1. Dari hasil jawaban siswa akan dianalisis menggunakan lima kriteria, yaitu tidak paham, miskonsepsi, miskonsepsi sebagian, paham sebagian, dan paham. Kelima kriteria tersebut terangkum dalam sebuah tabel yang ditunjukkan pada tabel 2 mengacu pada penilaian konsep dari (Abraham, et al, 1994).

Tabel 1. Indikator Taksonomi Bloom

\begin{tabular}{|c|l|c|}
\hline No & \multicolumn{1}{|c|}{ Indikator } & Soal No \\
\hline 1 & Menerapkan konsep tekanan hidrostatis dalam kehidupan sehari-hari (C3) & 1 \\
2 & Menentukan alat yang digunakan dari penerapan hokum pascal (C4) & 2 \\
3 & Menjelaskan tegangan permukaan suatu fluida (C2) & 3 \\
4 & Menganalisis tegangan permukaan suatu fluida (C3) & 4 \\
5 & Menganalisis besarnya massa jenis benda yang tercelup dalam suatu fluida & 5 \\
& terhadap gaya keatas (C4) & \\
\hline
\end{tabular}

Tabel 2. Kriteria Penguasaan Konsep

\begin{tabular}{|l|l|c|}
\hline \multicolumn{1}{|c|}{ Kategori } & \multicolumn{1}{|c|}{ Kriteria } & Kode Angka \\
\hline Tidak paham & Tidak ada jawaban & 0 \\
Miskonsepsi & Jawaban tidak sesuai & 1 \\
Miskonsepsi Sebagian & Jawaban mengandung konsep, tetapi masih salah & 2 \\
Paham sebagian & Jawaban mengandung beberapa bagian konsep & 3 \\
Paham konsep & Jawaban mengandung semua bagian konsep & 4 \\
\hline
\end{tabular}

\section{HASIL}

Hasil jawaban siswa dalam kegiatan pretest dan posttest untuk mengetahui penguasaan konsep siswa pada materi fluida statis. Uji analisis yang dilakukan ialah uji normalitas, homogenitas, dalam uji ini menunjukkan bahwa data terdistribusi normal dan juga homogeny. Selanjutnya, uji t berpasangan memiliki signifikansi 0,00 maka nilai 0,00 > 0,0005 yang berarti nilai signifikansi sebelum dan sesudah pembelajaran inkuiri terbimbing mengalami perubahan. 
Dalam penelitian yang dilakukan untuk mengukur penguasaan konsep siswa pada materi fluida statis terdapat empat sub materi, yaitu tekanan hidrostatis, hukum pascal, hukum Archimedes, dan tegangan permukaan. Pada soal-soal penguasaan konsep terdapat jawaban yang beraneka ragam. Kemampuan siswa dalam penguasaan konsep dapat dilihat dari nilai pretest dan posttest siswa. Berdasarkan hasil analisis Indikator Taksonomi Bloom diperoleh nilai statistik yang menunjukkan skor minimum, maksimum, dan nilai rata-rata serta standar deviasi ditunjukkan pada tabel 3.

Tabel 3. Statistik Hasil Taksonomi Bloom

\begin{tabular}{lc}
\hline Statistik & Nilai \\
\hline Minimal & 50 \\
Maxsimal & 95 \\
Median & 80 \\
Standar Deviasi & 13.83069
\end{tabular}

Penguasaan konsep siswa bukan hanya dilihat dari hasil analisis statistik, namun penguasaan konsep siswa dilihat dari hasil jawaban yang telah siswa kerjakan. Penilaian penguasaan konsep siswa dilakukan dengan berapa banyak siswa yang paham tentang konsep yang diberikan. Persentase penguasaan konsep siswa pada materi fluida statis ditunjukkan pada gambar 1 .

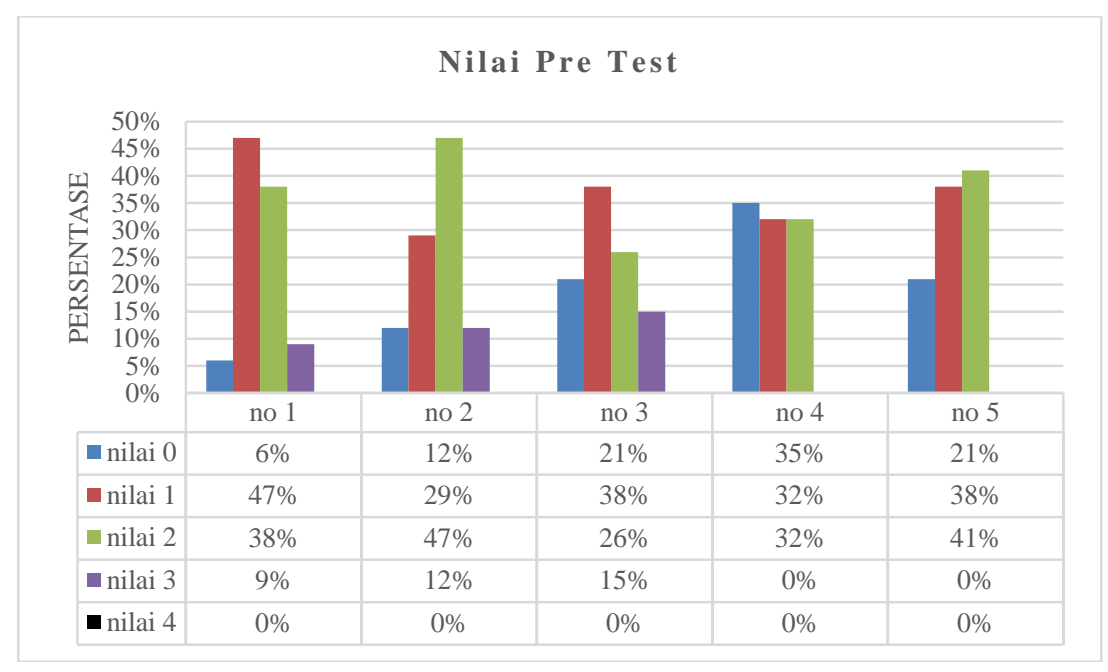

Gambar 1. Diagram Persentase Nilai Pretest Siswa

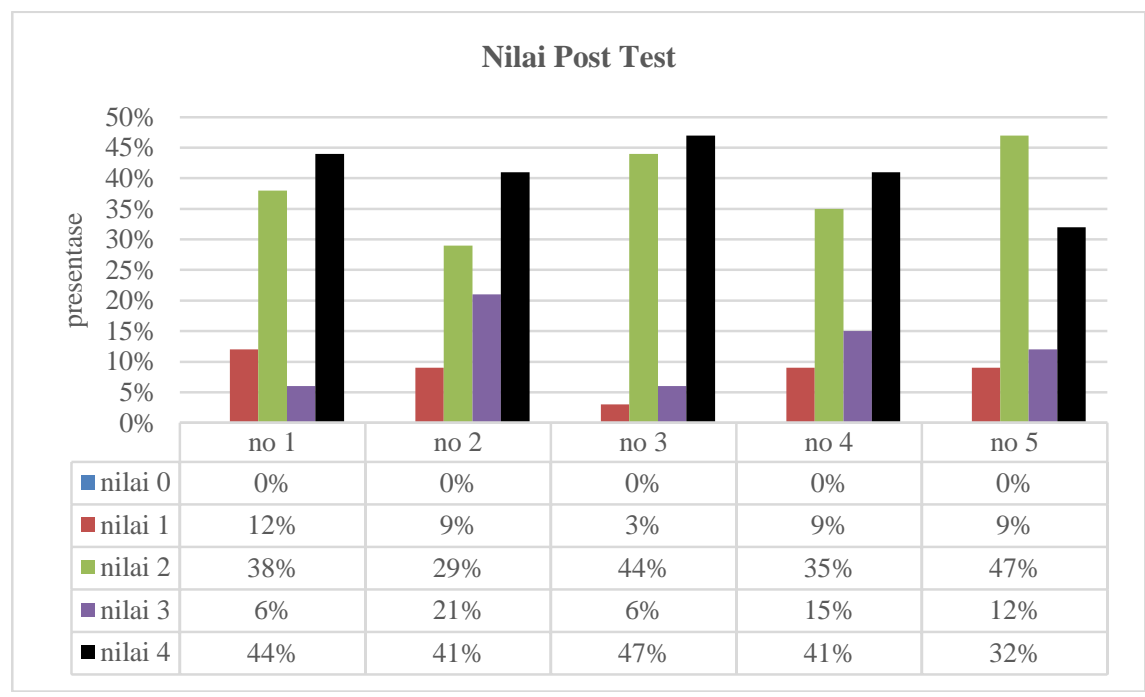

Gambar 2. Diagram Persentase Nilai Posttest 
Dari gambar diagram 1 dan 2, dapat kita lihat bahwa kriteria siswa dalam penguasaan konsep saat pretest dan posttest sangat berbeda. Dari diagram di atas menunjukkan ada peningkatan penguasaan konsep siswa. Kriteria penguasaan konsep yang mencakup, tidak paham, miskonsepsi, miskonsepsi sebagian, paham sebagian, dan paham konsep. Dari hasil analisis yang dilakukan menunjukkan bahwa hasil pretest dan posttest mengalami peningkatan. Pada soal nomor 1, penguasaan konsep siswa yang rata-rata berada pada kriteria miskonsepsi sebagian dengan jumlah $47 \%$ naik menjadi kriteria paham konsep dengan jumlah $44 \%$, dan nomor 2 pada pretest berada pada kriteria miskonsepsi sebagian dengan jumlah $47 \%$ setelah posttest siswa berada pada kriteria paham konsep dengan jumlah 41\%, dan nomor 3 pada saat pretest berada pada kategori miskonsepsi dengan jumlah $38 \%$ setelah posttest kriteria penguasaan konsep siswa berada pada kriteria paham konsep dengan jumlah $47 \%$, dan nomor 4 pada saat pretest berada pada kriteria tidak paham dengan jumlah $35 \%$ setelah posttest dilakukan siswa berada pada kriteria paham konsep dengan jumlah $41 \%$, dan nomor 5 pada saat pretest berada pada kriteria miskonsepsi sebagian dengan jumlah $41 \%$ dan setelah posttest dilakukan masih berada pada kriteria miskonsepsi sebagian, namun jumlahnya semakin yaitu $47 \%$. Hasil analisis ini dapat menunjukkan bahwa siswa mengalami peningkatan pada saat posttest dilakukan.

\section{Hasil Proyek Siswa}

Dari hasil proyek siswa pada materi Fluida Statis pada sub materi hukum Archimedes tentang melayang, terapung dan tenggelam. Para siswa membuat proyek alarm banjir sederhana yang dapat juga diaplikasikan pada bak mandi.

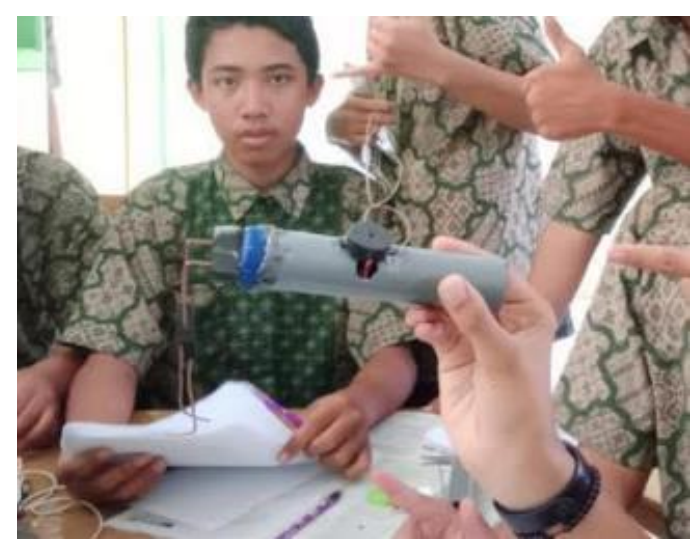

Gambar 3. Alarm Sederhana Hasil Siswa

Pada sub materi Hukum Archimedes menghasilkan satu proyek yang bernama alarm banjir sederhana dimana alat tersebut terbuat dari, pipa paralon, tutup botol minuman, kawat biasa, tembaga, baterai, buser, tombol on off, sterofom, tempat batrai, stik es cream, lem tembak. Alarm akan berbunyi ketika air melewati batas maksimum. Dengan prisip kerja tekanan air yang berada dibawah sterofom mengangkat sterofom hingga menyentuh kawat tembaga sehinggan alarm berbunyi. Karena sterofom lebih ringan daripada tekanan yang dihasilkan air. Hal ini sesuai dengan prinsip hukum Archimedes yang berbunyi apabila gaya ke atas lebih besar daripada berat, maka benda tersebut akan terapung.

Hasil jawaban siswa dalam kegiatan pretest dan posttest untuk mengetahui penguasaan konsep siswa pada materi fluida statis. Uji analisis yang dilakukan ialah uji normalitas, homogenitas, dalam uji ini menunjukkan bahwa data terdistribusi normal dan juga homogeny. Selanjutnya, uji t berpasangan memiliki signifikansi 0,00 maka nilai 0,00 >0,0005 yang berarti nilai signifikansi sebelum dan sesudah pembelajaran inkuiri terbimbing mengalami perubahan. Dalam penelitian yang dilakukan untuk mengukur penguasaan konsep siswa pada materi fluida statis terdapat empat sub materi, yaitu tekanan hidrostatis, hukum pascal, hukum Archimedes, dan tegangan permukaan. Pada soal-soal penguasaan konsep terdapat jawaban yang beraneka ragam.

\section{PEMBAHASAN}

Penguasaan konsep siswa pada materi fluida statis menunjukkan bahwa siswa mengalami perubahan yang sangat baik setelah mengerjakan dan membuat proyek. Hal ini dapat kita lihat dari hasil rata-rata nilai yang didapat siswa pada saat test yang dilakukan. Tes dilakukan dengan pretest dan posttest dengan soal yang sama. Pada saat posttest siswa sudah mengalami peningkatan daripada saat pretest hal ini menunjukkan bahwa persentase mencapai peningkatan. Hal ini diperkuat dengan penelitian bahwa penguasaan konsep dapat meningkatkan kekreatifan siswa (Arisanti, Sopandi, dan Widodo, 2016). 
Pada saat menggunakan model pembelajaran inkuiri terbimbing, siswa mengalami peningkatan dalam penguasaan konsep. Pada penelitian sebelumnya bahwa inkuiri terbimbing dapat meningkatkan kemampuan siswa. Dengan pembelajaran inkuiri terbimbing dapat meningkatkan penguasaan konsep pada siswa. Hal ini menunjukkan bahwa inkuiri terbimbing sangat memengaruhi penguasaan konsep siswa. Beberapa indikator penguasaan konsep siswa berada pada kategori paham konsep. Berdasarkan dari indikator $\mathrm{C} 2-\mathrm{C} 4$ rata-rata siswa sudah dapat menjawab soal dengan baik dan masuk pada kriteria paham konsep. Pada soal nomor 1, indikator menerapkan konsep tekanan hidrostatis dalam kehidupan sehari-hari (C3) rata-rata siswa berada pada kriteria paham konsep dengan jumlah $44 \%$ dan berada pada kriteria miskonsepsi $12 \%$, miskonsepsi sebagian $32 \%$ dan paham sebagian $6 \%$, sedangkan dalam kriteria tidak paham berjumlah $0 \%$. Dalam indikator ini meski belum $100 \%$, siswa paham konsep, tetapi sudah meningkat dari sebelumnya. Hal ini dikarenakan sebagian siswa masih bingung dalam menyelesaikan soal sampai selesai. Pada soal nomor 2, indikator menentukan alat yang digunakan dari penerapan Hukum Pascal (C4) siswa memiliki kriteria beranekaragam, siswa yang tidak paham konsep memiliki jumlah $0 \%$ miskonsepsi sebesar $9 \%$, miskonsepsi sebagian sebanyak 29\%, paham sebagian $21 \%$, paham konsep $41 \%$. Pada soal nomor 3, indikator Menjelaskan tegangan permukaan suatu fluida (C2) siswa memiliki kriteria tidak paham sebanyak 0\%, miskonsepsi 3\%, miskonsepsi sebagian $44 \%$, paham sebagian $6 \%$, paham konsep $47 \%$.

Pada soal nomor 4, indikator menganalisis tegangan permukaan suatu fluida (C3) siswa memilki kriteria tidak paham $0 \%$, miskonsepsi $9 \%$, miskonsepsi sebagian $35 \%$, paham sebagian $15 \%$, dan paham konsep $41 \%$. Pada soal nomor 5 , indikator Menganalisis besarnya massa jenis benda yang tercelup dalam suatu fluida terhadap gaya ke atas (C4) kriteria siswa berada pada kategori tidak paham 0\%, miskonsepsi 9\%, miskonsepsi sebagian 47\%, paham sebagian 12\%, dan paham konsep 32\%. Hasil ini menunjukkan bahwa kriteria penguasaan konsep siswa sudah ada pada kriteria paham konsep meskipun sebagian siswa belum mencapai kriteria yang sama. Selain itu, dari hasil proyek siswa pada pembuatan alarm banjir sederhana, siswa menunjukkan keaktifannya dalam mencari dan merakit alat sendiri serta dengan adanya proyek membuat siswa mendapatkan pengalaman baru yang belum pernah mereka dapat. Dalam sebuah penelitian lain menunjukkan bahawa suatu pembelajaran dikatakan berhasil dengan menggunakan penguasaan konsep (Jannah, Yuliati, dan Parno 2016). Hal ini juga dikuatkan oleh penelitian menyatakan penguasaan konsep itu lebih bermanfaat daripada siswa menghafal sebuah materi (Cakir, 2008).

Dalam sebuah penelitian menyatakan bahwa pembelajaran menggunakan STEM sangat bermanfaat buat siswa hal ini sesuai dengan penelitian, siswa yang telah mendapatkan pembelajaran berbasis STEM mengalami peningkatan pada konteks STEM dengan begini maka meningkatkan hal yang lain (Kheruningtyas, Permanasari, dan Hamidah, 2016). Dalam penelitian lain menyatakan bahwa STEM dapat meningkatkan penguasaan pengetahuan, dari pengetahuan yang mereka miliki mereka aplikasikan dengan hal-hal yang baru sehingga dapat menciptakan sesuatu dari sebuah masalah (Permanasari, 2016). STEM juga dapat mengajarkan siswa dalam subjek yang memiliki panduan (Breiner, et al, 2012), (Lestari, Sarwi, dan Sumarti 2018). STEM meningkatkan siswa dalam pengaplikasian teknologi (Kapila and Iskander 2014).

\section{SIMPULAN}

Berdasarkan penelitian yang telah kita lakukan terdapat perbedaan yang signifikan penguasaan konsep siswa SMAN 6 Malang sebelum pembelajaran dan sesudah pembelajaran dilakukan dengan menggunakan model inkuiri terbimbing pada materi fluida statis $(0,00>0,0005)$. Hasil ini menunjukkan bahwa terdapat pengaruh pembelajaran inkuiri terbimbing berbasis STEM terhadap penguasaan konsep siswa. Artinya, siswa memiliki nilai yang meningkat pada saat posttest dialakukan. Kriteria penguasaan konsep siswa pada saat pretest dan posttest mengalami peningkatan. Adapun saran untuk penelitian selanjutnya, disarankan untuk mengunakan model-model pembelajaran yang lain disertai modifikasi yang terbaru.

\section{DAFTAR RUJUKAN}

Abraham, R Michael, M Vickie, Williamson, L Susan., \& Westbrook. (1994). A Cross-Age Study of the Understanding of Five Chemistry Concepts. Journal of Research in Science Teaching, 31(2), 147-165.

Afriana, J., Permanasari, A., \& Fitriani, A. (2016). Penerapan Project Based-Learning Terintegrasi STEM untuk Meningkatkan Literasi Sains Siswa Ditinjau dari Gender. Jurnal Inovasi Pendidikan IPA, 2(2), 202. https://doi.org/10.21831/jipi.v2i2.8561.

Anderson, L. W., \& Krathwohl, D. R. (2010). Kerangka Landasan untuk Pembelajran, Pengajaran dan Asesmen (Revisi Taksonomi Pendidikan Bloom). Yogyakarta: Pustaka Pelajar.

Arisanti, W. O. L., Sopandi, W., \& Widodo, A. (2016). Analisis Penguasaan Konsep dan Keterampilan Berpikir Kreatif Siswa SD melalui Project Based Learning. EDUHUMANIORA: Jurnal Pendidikan Dasar, 8(1), 82-95.

Asghar, A., Ellington, R., \& Rice, E. (2012). Supporting STEM Education in Secondary Science Contexts. Interdisciplinary Journal of Problem-Based Learning, 6(2), 85-125. https://doi.org/10.7771/1541-5015.1349

Bilgin, I. Y., Karakuyu, Y., \& Ay, Yusuf. (2015). The Effects of Project Based Learning on Undergraduate Students Achievementand Self-Efficacy Beliefs Towards Science Teaching. Eurasia Journal of Mathematics, Science \& Technology Education 11(3), 469-477. 
Breiner, J. M., Harkness, S. S., Johnson, C., \& Koehler, C. M. (2012). What Is STEM? A Discussion about Conceptions of STEM in Education and Partnerships. School Science and Mathematics, 112(1) 3-11.

Cakir, M. (2008). Constructivist Approaches to Learning in Science Their Implication for Science Pedagogy: A Literature Review. Internasional Journal of Environmental \& Science Education, 3(4), 409-420.

Goszwski, M. A., Moyer, Z Bazar., \& Wagner, D. J. (2013). Exploring Student Difficulties with Pressure in a Fluid. AIP Conference Prociding, 1513(1), 154-157.

Hung, W., \& Jonassen, D. H. (2006). Conceptual Understanding of Causal Reasoning in Physics. International Journal of Science Education, 28(13), 1601-1621. https://doi.org/10.1080/09500690600560902.

Jannah, A. F., Yuliati, L., \& Parno. (2016). Penguasaan Konsep dan Kemampuan Bertannya Siswa pada Materi Hukum Newton Melalui Pembelajran Inquiry Lesson dengan Strategi LBQ. Jurnal Pendidikan, Teori, Penelitian, dan Pengembangan, 1(3), 409-420.

Jonassen, D. H. (2003). Designing Research-Based Intruction for Story Problems. Education Psychology Review 15(3), 267296.

Joyce, B., Weil, M., \& Calhoun, E. (2009). Models of Teaching ( $8^{\text {th }}$ ed). Model-Model Pengajaran (Terjemahan Achmad Fawai \& Ateilla Mirza). Yogyakarta: Pustaka Pelajar.

Kapila, V., \& Iskander, M. (2014). Lessons Learned Fromconducting a K-12 Project to Revitalize Achievement by Using Instrumentation in Science Education. Journal of STEM Education: Innovations and Research, 15(1), 46-51.

Kementrian Pendidikan Malaysia. (2016). Panduan Pelaksanaan Sains, Teknologi, Kejuruteraan dan Matematik (STEM) Dalam Pengajaran dan Pembelajaran. Malaysia: Kementrian Pendidikan Malaysia.

Kheruningtyas, N., Permanasari, A., \& Hamidah, I. (2016). STEM Learning in Material of Temperature and Its Change to Improve Scientific Literacy of Junior High School. Jurnal Pendidikan IPA Indonesia, 5(1), 94-100. DOI: 10.15294/jpii.v5i1.5797

Kim, M. K., \& Cho, M. K. (2015). Design and Implementation of Integrated Instruction of Mathematics and Sciencein Korea. Eurasia Journal of Mathematics, Science \& Technology Education, 11(1), 3-15.

Lestari, T. P., Sarwi., \& Sumarti, S. S. (2018). STEM-Based Project Learning Model Toincrease Science Process and Creative Thinking Skill of 5th Grade. Journal of Primary Education, 7(1), 18-24.

Loverude, M. E., Heron, P R L., \& Kautz, C. H. (2010). Identifying and Addressing Student Difficulties with Hydrostatic Pressure. American Jurnal of Physics, 78(1).

Maloney, D.P, T. I O'kuma, C. J Higgelke., \& A Van Heuvalen. (2001). Surveying Students' Conceptual Knowledge of Electricity and Magnetis. American Journal of Physics, 69(SI) 12-23. https://doi.org/10.1119/1.1371296.

Marlis. (2015). Analisis Profil Pemahaman Konsep dan Konsistensi Konsepsi Siswa Kelas X SMA Negeri 1 Tilatang Kemang pada Materi Fluida Statis. Proseding Simposium Nasional Inovasi dan Pembelajaran Sains 2015.

Praptiwi, L., Sarwi., \& Handayani, L. (2012). Efektivitas Model Pembelajaran Eksperimen Inkuiri Terbimbing Berbantuan My OWN Dictonary untuk Meningkatkan Penguasaan Konsep dan Unjuk Kerja Siswa SMP RSBI. Unnes Science Education Journal, 1(2), 86-95.

Shih, J. L, Chuang, C.W., \& Hwang, G. J. (2010). Inquiry-Based Mobile Learning Approach to Enhancing Social Science Learning Effectiveness. Journal of Educational Technology \& Society, 13(4), 50-62.

Simanjuntak, M. P. (2014). Efektivitas Model Problem Based Learning terhadap Penguasaan Konsep Mahasiswa pada Konsep Suhu dan Kalor. Jurnal Inpafi (Inovasi Pembelajaran Fisika), 2(3), 126-133.

Hadiati, S., \& Pramuda, A. (2013). Pembelajaran Fisika Beriorientasi Pendidikan Karakter dengan Metode Inkuiri Terbimbing dan Inkuiri Bebas Termodifikasi pada Materi Fluida Statis. Jurnal Edukasi Matematika dan Sains, 1(1), 28 -30.

Stohlmann, M., Moore, T. J, \& Roehrig, G. H. (2012). Considerations for Teaching Integrated STEM Education. Journal of Pre-College Engineering Education Research (J-PEER) 2-4.

Van Heuvelen, A. (1991). Learning to Think Like a Physicist: A Review of Research-Based Instructional Strategies. American Journal of Physics, 59(10), 891-897. https://doi.org/10.1119/1.16667.

Yin, Y. F., Tomita, M. K., \& Shavelson, R. J. (2008). Diagnosing and Dialling with Student Misconception: Floating and Sinking. Science Scope, 31(8), 34-39.

Yusro, A. C., \& Sasono, M. (2016). Penggunaan Model Ilustrasi Berbasis Inkuiri Terbimbing Pokok Bahasan Kinematika Gerak Lurus untuk Meningkatkan Hasil Belajar dan Kemandirian Siswa Kelas VII SMPN 14 Madiun. Jurnal Pendidikan Fisika dan Keilmuan (JPFK), 2(1), 29-35. http://dx.doi.org/10.25273/jpfk.v2i1.22. 